\title{
Analisis Dampak Kurangnya Sadar Wisata dan Doktrin Kota Santri Terhadap Perkembangan Pariwisata di Kabupaten Pandeglang Banten
}

\author{
Surachman $^{a}$, Suhandi ${ }^{b}$ \\ aUniversitas Bina Bangsa, rachmanbjr@gmail.com \\ bUniversitas Bina Bangsa, suhandihitam@gmail.com
}

\begin{abstract}
A b s t r a k
Sektor pariwisata saat ini telah menjadi aspek penting dalam kemajuan ekonomis suatu negara. Kabupaten Pandeglang merupakan daerah banyak memiliki potensi wisata, namun dalam proses perkembangannya masih jauh tertinggal dari daerah lain. Tujuan dari Penelitian ini adalah untuk menganalisa dan mengkaji faktor apa yang mempengaruhi sehingga masih banyak warga Pandeglang yang belum sadar wisata dan untuk mengkaji mengapa doktrin kota santri begitu kuat terhadap warga Pandeglang sehingga berpengaruh terhadap perkembangan pariwisata di Kabupaten Pandeglang. Metode yang di gunakan dalam penelitian ini adalah Metode Kualitatif dengan proses observasi, wawancara, dan dokumentasi dengan analisis matriks SWOT untuk mengetahui kekuatan, kelemahan, peluang dan ancaman dalam pengembangan potensi wisata yang ada di Kabupaten Pandeglang.Informan terdiri dari: Dinas pariwisata dan ekonomi kreatif Pandeglang, pengelola wisata, pokdarwis, tokoh agama, akademisi, wisatawan, masyarakat Pandeglang, penelitian dilakukan selama satu tahun.Sedangkan strategi yang tepat dilakukan dalam pengembangan pariwisata di Kabupaten Pandeglang adalah strategi Strategi SO (Growth). Strategi SO (Growth) merupakan strategi yang memanfaatkan kekuatan yang ada untuk meningkatkan keunggulan kompetitifnya.Hasil dari penelitian ini menunjukan bahwa banyak faktor yang menyebabkan pariwisata di Pandeglang perkembanganya masih jauh tertinggal antara lain: masih kurangnya masyarakat akan sadar wisata, masih kurangnya pembentukan kelompok sadar wisata (Pokdarwis) di setiap Desa/ Kelurahan yang ada di Kabupaten Pandeglang, kurangnya sosialisasi terkait pemahaman doktrin kota santri, masih kurangnya promosi wisata baik secara online maupun off line dan minimnya anggaran belanja daerah Kabupaten Pandeglang dalam hal ini Dinas Pariwisata dan Ekonomi Kreatif Kabupaten Pandeglang.
\end{abstract}

Kata Kunci: Sadar Wisata, kota santri, pariwisata.

\section{A b s t r a c t}

The tourism sector has become an important aspect in the economic progress of a country. Pandeglang Regency is an area with a lot of tourism potential, but in the process of its development it is still far behind other areas. The purpose of this study is to analyze and examine what factors influence so that there are still many Pandeglang residents who are not aware of tourism and to study why the city doctrine of students is so strong against Pandeglang residents that it affects the development of tourism in Pandeglang Regency. The method used in this study is a qualitative method with a process of observation, interviews, and documentation with a SWOT matrix analysis to determine the strengths, weaknesses, opportunities and threats in developing tourism potential in Pandeglang Regency. The informants consist of: the tourism and creative economy office. Pandeglang, tourism managers, pokdarwis, religious leaders, academics, tourists, the people of Pandeglang, the research was carried out for one year. While the right strategy in developing tourism in Pandeglang Regency is the SO Strategy (Grwth). The SO (Growth) strategy is a strategy that utilizing existing strengths to increase its competitive advantage. The results of this study indicate that many factors cause tourism in Pandeglang to be still far behind, among others: there is still a lack of awareness of tourism, there is still a lack 
of formation of a tourism awareness group (Pokdarwis) in every Desa/ Kelurahan in Pandeglang Regency, lack of socialization related to understanding the doctrine of the city of students, there is still a lack of tourism promotion both online and off line and the lack of regional budget for Pandeglang Regency, in this case the Tourism and Creative Economy Office of Pandeglang.

Keywords: Tourism awareness, city of students, tourism.

\section{Pendahuluan}

Sektor pariwisata saat ini telah menjadi aspek penting dalam kemajuan ekonomisuatu negara. Pariwisata menjadi pilihan utama dalam pengembangan wilayah. Perkembangan pariwisata telah mengalami banyak perubahan baik perubahan pola, bentuk dan sifat kegiatan perjalanan destinasi wisata, dan lain-lain. Pembangunan suatu daerah dapat membuka daya tarik wisata baru bagi para wisatawan, baik wisatawan asing maupun lokal. Potensi pariwisata di Indonesia yang amat sangat melimpah dapat mengangkat ekonomi negara apabila setiapobyeknya dikelola dengan baik oleh pemerintah maupun pihak-pihak disekitar obyek wisata tersebut sehingga banyaknya kunjungan wisatawan akanberpengaruh pada naiknya devisa negara.

Alasan pemilihan Kabupaten Pandeglang sebagai objek atau tempat penelitian di bandingkan kabupaten yang ada di Provinsi Banten, karena di Kabupaten Pandeglang banyak memiliki banyak potensi tempat wisata, baik wisata pantai, wisata alam, wisata religi, wisata kuliner. Sektor pariwisata di Kabupaten Pandeglang merupakan sektor yang diunggulkan dan berkontribusi terhadap PDRB (Pendapatan Daerah Regional Bruto) Kabupaten Pandeglang setiaptahunnya. Hal ini disebabkan oleh banyaknya Objek Daya Tarik Wisata (ODTW) pesonan keindahan alam yang berpadu dengan keragaman budaya, kesenian, sejarah maupun kuliner yang ada dan tersebar di beberapa kecamatan di Kabupaten Pandeglang.Usaha pelestarian terhadap ODTW di Kabupaten Pandglang perlu diperhatikan dengan baik karena Kabupaten Pandeglang memiliki tingkat ketergantungan yang besar dari sektor pariwisata.

Dalam proses perkembangan dan kemajuan pariwisata di Kabupaten Pandeglang, baik wisata pantai, wisata alam, wisata religi, wisata kuliner dan wisata lainya, masih jauh tertinggal di bandingkan dengan daerah lain baik yang ada di sekitar Provinsi Banten maupun daerah lain di Indonesia. Ada beberapa faktor yang mempengaruhi lambatnya perkembangan potensi wisata yang ada di Kabupaten Pandeglang, selain Anggaran Dana Daerah yang masih minim dalam pengelolaan pariwisata yang ada di Kabupaten Pandeglang, apalagi setelah di terjang Tsunami Selat Sunda 22 Desember 2018. Ada dua Faktor yang memberikan pengaruh yang luar biasa dalam proses lambatnya perkembangan atau pariwisata yang ada di Kabupaten Pandeglang yaitu sumber daya manusia warga Pandeglang itu sendiri di mana masih banyak warga Pandeglang terutama yang berada di sekitar tempat wisata baik wisata pantai, wisata alam, wisata religi dan lain sebagainya, yang masih kurang sadar wisata dan doktrin kota santri yang melekat di benak warga Pandeglang itu sendiri, dengan julukan kota santri dan kota sejuta ulama, dimana peran tokoh agama atau di Kabupaten Pandglang sangat kuat, termasuk kebijakan pemerintah daerah, sehingga segala sesuatu dikaitkan dengan hukum agama Islam. 
Tabel 1

Daftar Nama Potensi Wisata di Kabupaten Pandeglang Banten

\begin{tabular}{|c|c|c|}
\hline No. & NamaPotensiWisata & Keterangan \\
\hline 1. & WisataPantai & 66 Titik/ Tempat \\
\hline 2. & Mata Air & 6 Titik/Tempat \\
\hline 3. & Air Terjun & 18 Titik/ Tempat \\
\hline 4. & Situs & 3 Titik/Tempat \\
\hline 5. & PemandianBuatan & 10. Titik/Tempat \\
\hline 6. & Pulau & 32. Titik/Tempat \\
\hline 7. & Pegunungan & 6. Titik/Tempat \\
\hline 8. & SitusCagarBudaya & 61. Titik/Tempat \\
\hline 9. & BangunanSejarah & 12. Titik/Tempat \\
\hline 10. & WisataZiarah/Religi & 91 Titik/Tempat \\
\hline
\end{tabular}

Sumber: data Dinas Pariwisata Kabupaten Pandeglang Tahun 2020

Tabel 2

Data Kunjungan Wisatawan Tiga Tahun Terakhir di Pandeglang

\begin{tabular}{|l|c|c|c|c|}
\hline No. & Tahun Kunjungan & Wisnus & Wisman & Total Jumlah Kunjungan \\
\hline 1 & 2018 & 3.102 .472 & 2.579 & 3.105 .051 \\
\hline 2 & 2019 & 2.404 .023$. & 2.370 & 2.406 .393 \\
\hline 3 & 2020 & 1.818 .623 & 2.070 & 1.818 .623 \\
\hline
\end{tabular}

Sumber: data Dinas Pariwisata Kabupaten Pandeglang Tahun 2020

Banyak contoh beberapa potensi wisata yang ada di Kabupaten Pandeglang seperti di kawasan wisata gunung karang, kawasan wisata gunung Pulosari Mandalawangi, dankawasanpantai, dimana di beberapa kawasan wisata tersebut punya potensi wisata bagus untuk di kembangkan, tetapi sulit sekali untuk di kembangkan karena masyarakat sekitar kawasan tersebut masih banyak yang belum sadar akan wisata, banyak mereka yang menolak untuk diajak bekerja sama dengan Dinas terkait dalam hal ini Dinas Pariwisata Kabupaten Pandeglang dan aparat Desa setempat, dalam meningkatkan perkembangan atau kemajuan potensi wisata yang di sekitar wilayah mereka dengan beberapa alasan diantaranya lahan tersebut merupakan peninggalan orang tua mereka, lahan mereka takut rusak dan hilang, lahan mereka takut dijadikan tempat maksiat, segala sesuatu dikaitkan dengan hukum agama Islam, banyak larangan

Ada beberapa tempat wisata yang ada di Kabupaten yang sudah berjalan dan tidak ada penambahan tempat lain, seperti Kawasan wisata Pantai Carita, Tanjung Lesung, Pemandian Cikoromoy (Batu Qur'an), Pemandian Air Panas Cisolong, Kampung Domba, Landmark Pandeglang, Lembur Kula, Kawasan Pegunungan Pulosari, dan lain sebagainya.Menurut hasil observasi ke lapangan beberapa tempat wisata tersebut di atas masih sepi pengunjung, di sebabkan beberapa faktor : banyak pungutan liar, kurang nyaman, tidak ada inovasi tempat wisata, sarana dan prasarana masih belum mendukung, dan lain sebagainya di tambah adanya pandemi Covid-19, sehingga perkembangannya masih kurang meningkat.

Hasil temuan penelitian yang dilakukan Wijaya (2019) menunjukan bahwa pengelolaan objek wisata air Cikoromoy masih kurang baik perlu adanya pengembangan 
kea arah yang lebih baik dalam rangka meningkatkan perkembangan objek pariwisata di Kabupaten Pandeglang. Sehingga sampai sekarang perkembangan dunia pariwisata Kabupaten Pandeglang masih jauh tertinggal di bandingkan dengan daerah lain baik yang ada di sekitar Banten maupun dengan daerah lain yang ada di Indonesia dan juga belum ada kebijakan seperti apa yang akan di persiapkan Pemerintah Daerah Kabupaten Pandeglang, dimana kebijakan tersebut akan di jadikan pedoman bagi para pelaku usaha pariwisata, dalam rangka meningkatkan perkembangan dunia pariwisata di Kabupaten Pandeglang.Rumusan masalah: kurangnya sadar wisata, kuatnya doktrin kota santri, masih kurangnya kelompok sadar wisata. Tujuan penelitian untuk mengkaji dan menganalisa kurangnya sadar wisata dan doktrin kota terhadap perkembangan pariwisata di Kabupaten Padneglang.

\section{Landasan Teori}

\subsection{Pariwisata}

Pariwisata dapat juga diartikan sebagai perjalanan yang dilakukan berkali-kali atau berputar-putar dari suatu tempat ketempat yang lain. Pengembangan dan pembangunan kepariwisataan merupakan bagian integral dari pembangunan nasional, yang dilakukan secara sistematis, terencana, terpadu, berkelanjutan dan bertanggung jawab (Akib, 2020). Pengembangan pariwisata dipandang sebagai cara untuk meningkatkan ekonomi dan kesejahteraan sosial suatu negara (Risman et., al, 2016; Adnyana, 2020). Menurut Indriani, et al., (2020) bahwa sektor pariwisata Indonesia telah mampu berperan menjadi salah satu penyumbang dana yang cukup signifikan terhadap pendapatan daerah diseluruh penjuru nusantara. Saat ini, destinasi wisata di Indonesia tidak terbatas hanya pada wisata kuliner, alam, budaya, dan sejarah akan tetapi wisata religi telah hadir sebagai destinasi atau pilihan wisata bagi wisatawan (Setyowati, 2019).

\subsection{Sadar Wisata dan Kota Santri}

Sadar wisata merupakan sebuah konsep yang menggambarkan partisipasi dan dukungan segenap komponen masyarakat dalam mendorong terwujudnya iklim yang kondusif bagi tumbuh dan berkembangnya kepariwisataan di suatu wilayah dan bertujuan untuk meningkatkan kesejahteraan rakyat. Potensi wisata alam Indonesia memiliki kekayaan yang melimpah jika dikombinasikan dengan industri ekonomi maka akan menciptakan peluang besar bagi peningkatan pendapatan negara (Indriani, et al., 2020).

Pariwisata di Indonesia menjadi salah satu peluang peningkatan ekonomi masyarakat, terkhusus pariwasata halal di Indonesia saat ini menjadi daya tarik tersendiri bagi wisatawan lokal maupun mancanegara. Sebuah kota yang menjadi tujuan wisata belajar agama telah melakukan upaya untuk menonjolkan karakteristik khusus yang dimiliki salah satunya melalui City branding dan City Image. City Branding identik dengan konsep pemasaran kota sebagai sebuah produk. Sedangkan, City Branding merupakan identitas, simbol, logo, atau merek yang melekat pada kota atau daerah (Santoso, 2017). Istilah kota santri tidak boleh hanya disematkan pada kota atau daerah yang memiliki banyak pesantren. Akan tetapi harus lebih dari itu, yakni haruslah merujuk pada karakteristik masyarakat yang sangat kental dengan kegiatan keagamaan dan prilaku 
sosial yang kental dengan nilai-nilai moralitas. Kota santri haruslah menjadi simbol peradaban kota atau daerah.

\section{Metode Penelitian}

Penelitian ini dilakukan di kawasan wisata di Kabupaten Pandeglang.Penelitian ini menggunakan metode kualitatif deskriftip melalui proses obsevasi, wawancaa dan dokumentasi kemudian disajikan dalam bentuk data. Metode Analisis yang digunakan yaitu analisis SWOT. Metode analisis SWOT terdiri dari pengambungan unsure kekuatan (Strengths), kelemahan (Weaknesses), peluang (Opportunities), dan ancaman (Threats) yang mampu menghasilkan suatu strategi yang didasarkan pada situasi lingkungan internal dan eksternal (Qamaruddin et al., 2019). Informan yang digunakan pada penelitian ini yaitu Dinas Pariwisata dan Ekonomi Kreatif Kabupaten Pandeglang, Pihak Akademisi, Tokoh Agama, Pengelola Wisata, Wisatawan, Pokdarwis, Masyarakat Pandeglang.

\section{Hasil dan Pembahasan}

\subsection{Gambaran Karakteristik Objek Penelitian}

Kabupaten Pandeglang, adalah sebuah Kabupaten di Provinsi Banten. Ibukotanya adalah Pandeglang. Kabupaten ini berbatasan dengan Kabupaten Serang di utara, Kabupaten Lebak di Timur, serta Samudra Indonesia di barat dan selatan. Wilayahnya juga mencakup Pulau Panaitan (di sebelah barat, dipisahkan dengan Selat Panaitan), serta sejumlah pulau-pulau kecil di Samudra Hindia, termasuk Pulau Deli dan Pulau Tinjil. Semenanjung Ujung Kulon merupakan ujung paling barat Pulau Jawa, dimana terdapat suaka margasatwa tempat perlindungan hewan badak bercula satu yang kini hampir punah.

$\begin{array}{ll}\text { Motto } & \text { : BERKAH (Bersih, Elok, Ramah, Kuat, Aman, Hidup) } \\ \text { Provinsi } & \text { : Banten } \\ \text { Ibu Kota } & : \text { Pandeglang } \\ \text { Luas } & : 2.746 .90 \mathrm{Km} 2 \\ \text { Posisi Geografis } & : 6^{0} 21^{\prime}-7^{0} 10^{\prime} \mathrm{LS} \text { and } 104^{0} 48^{\prime}-106^{0} 11^{\prime} \mathrm{BT} \\ \text { Suhu Rata-Rata } & : 22.5^{\circ} \mathrm{C}-27.9^{\circ} \mathrm{C} \\ \text { Jumlah Penduduk } & : 1.209 .011(2018) \\ \text { Kepadatan Penduduk } & : 100 \mathrm{jiwa} / \mathrm{km} 2 \\ \text { Jumlah Kecamatan } & : 35 \\ \text { Jumlah Desa/Kelurahan: } 335\end{array}$

Karakteristik utama Kabupaten Pandeglang adalah ketinggian gunung-gunungnya yang relatif rendah, seperti Gunung Payung (480 m), Gunung Honje (620 m), Gunung Tilu (562 m) dan Gunung Raksa (320 m). Daerah Utara memiliki luas 14,93\% dari luas Kabupaten Pandeglang yang merupakan dataran tinggi, yang ditandai dengan karekteristik utamanya adalah ketinggian gunung yang relatif tinggi, seperti Gunung Karang (1.778 m), Gunung Pulosari (1.346 m) dan Gunung Aseupan (1.174 m). 


\subsection{Hasil Observasi Data}

Untuk menjawab masalah penelitian dapat dilakukan pula dengan cara pengamatan. Pengamatan (observasi) yakni mengamati gejala yang diteliti. Penelitian di mulai dengan membuat surat ijin penelitian ke Kantor Dinas Penanaman Modal dan Pelayanan Satu Pintu Kabupaten Pandeglang.Selanjutnya Tim Peneliti melakukan kunjungan ke Kantor Dinas Pariwisata Kabupaten Pandeglang, untuk bersilaturahmi dan mengajukan surat rekomendasi ijin penelitian ke tempat - tempat wisata yang ada di sekitar wilayah Kabupaten Pandeglang.Selanjutnya Tim Peneliti melakukan observasi ke beberapa tempat potensi wisata yang ada di Kabupaten Pandeglang mulai dari wisata pantai, Mata air, Air Terjun, Situs, Pemandian, Pulau, Pegunungangan, Situs Cagar Alam, Bangunan sejarah, dan Wisata Religi.Dengan melakukan observasi Tim Peneliti dapat mengetahui kondisi di lapangan terkait potensi wisata yang ada di Kabupaten Pandeglang.

Dari hasil obeservasi menemukan bahwa kondisi Potensi Pariwisata yang ada di Kabupaten Pandeglang mempunyai potensi yang baik untuk dikembangkan, namun selama ini perkembangannya masih jauh dari harapan, dan permasalahan ini di sebabkan beberapa faktor diantaranya : masih banyak warga yang ada di sekitar tempat potensi wisata yang ada di Kabupaten Pandeglang, masih banyak warga yang belum sadar wisata, masih kurang pembentukan kelompok sadar wisata di setiap kelurahan dan desa yang ada di Kabupaten Pandeglang dan masih kuatnya Doktrin Kota Santri di kalangan warga Kabupaten Pandeglang, dimana segala sesuatu di kaitkan dengan hukum agama islam.Dimana masih banyak warga yang ada disekitar tempat wisata atau pemilik lahan potensi wisata yang sulit untuk diajak kerjasama dalam proses pengembangan kawasan wisata baik oleh Dinas Pariwisata Kabupaten Pandeglang maupun Pihak swasta dengan beberapa alasan diantaranya : lahan tersebut milik peninggalan orang tua mereka, lahan mereka takut di jadikan tempat maksiat, lahan mereka takut hilang, segala sesuatu dikaitkan dengan hukum agama islam dan banyak larangan dan lain sebagainya.

\subsection{Hasil Wawancara}

Wawancara dilakukan oleh tim peneliti terhadap beberapa nara sumber diantaranya Dinas Pariwisata Kabupaten Pandeglang, Pengelola wisata yang ada di Pandeglang, Pengunjung atau wisatawan yang ada di Kawasan wisata di Kabupaten Pandeglang, Masyarakat atau warga yang ada di kawasan wisata di Kabupaten Pandeglang, Tokok Agama yang ada di Kabupaten Pandeglang dan Pihak Akademisi.

\section{Tabel 3}

\section{Hasil Wawancara dengan Pihak Terkait di Kabupaten Pandeglang}

\begin{tabular}{|c|l|l|l|}
\hline No. & Nama Pihak Terkait & \multicolumn{1}{|c|}{ Pertanyaan } & \multicolumn{1}{c|}{ Jawaban } \\
\hline 1. & $\begin{array}{l}\text { Kepala Dinas Pariwisata } \\
\text { Pandeglang }\end{array}$ & $\begin{array}{l}\text { Sejauh mana } \\
\text { perkembangan } \\
\text { pariwisata di } \\
\text { Kabupaten } \\
\text { Pandeglang? }\end{array}$ & $\begin{array}{l}\text { Selama ini perkembangan pariwisata di } \\
\text { Pandeglang masih belum berkembang } \\
\text { pesat, masih jauh di bandingkan daerah } \\
\text { lain, tapi kami tetap terus berusaha } \\
\text { dengan kemampuan yang kami miliki } \\
\text { baik dana, sdm, dan lain-lain. }\end{array}$ \\
\hline 2. & $\begin{array}{l}\text { Kepala Dinas Pariwisata } \\
\text { Pandeglang }\end{array}$ & $\begin{array}{l}\text { Faktor-faktor } \\
\text { apa }\end{array}$ & $\begin{array}{l}\text { Faktor utamanya adalah masih kurang } \\
\text { sadar wisata dan masih kuatnya doktrin }\end{array}$ \\
\hline
\end{tabular}




\begin{tabular}{|c|c|c|c|}
\hline & & $\begin{array}{l}\text { menyebabkan } \\
\text { Perkembangan } \\
\text { Pariwisata di } \\
\text { Kabupaten } \\
\text { Pandeglang, } \\
\text { masih jauh } \\
\text { tertinggal? } \\
\end{array}$ & $\begin{array}{l}\text { kota santri pada masyarakat Pandeglang } \\
\text { itu sendiri. }\end{array}$ \\
\hline 3. & $\begin{array}{l}\text { Kepala Dinas Pariwisata } \\
\text { Pandeglang }\end{array}$ & $\begin{array}{l}\text { Kira-kira usaha } \\
\text { apa yang terus } \\
\text { dilakukan pihak } \\
\text { Dinas } \\
\text { Paariwisata, } \\
\text { dalam rangka } \\
\text { meningkatkan } \\
\text { perkembangan } \\
\text { pariwisata di } \\
\text { Pandeglang? }\end{array}$ & $\begin{array}{l}\text { Kami terus berusaha untuk membangun } \\
\text { pariwisata di kabupaten Pandeglang, } \\
\text { walaupun dengan keterbatasan anggaran } \\
\text { dana daerah, kami terus menggali } \\
\text { potensi-potensi wisata yang ada di } \\
\text { Pandglang. } \\
\text { 1.Dengan membentuk Pokdarwis di } \\
\text { setiap Kelurahan atau Desa yang ada di } \\
\text { Pandeglang dan mensosialisasikan peran } \\
\text { dari Pokdarwis itu sendiri. } \\
\text { 2.Bekerjasama denga para tokoh agama } \\
\text { atau alim ulama yang ada di di } \\
\text { Pandeglang terkait pemahaman Doktrin } \\
\text { Kota Santri }\end{array}$ \\
\hline 4. & $\begin{array}{l}\text { Tokoh Agama Islam } \\
\text { Pandeglang } \\
\text { (KH. Bayi Sanusi) }\end{array}$ & $\begin{array}{l}\text { Bagaimana } \\
\text { pendapat bapak } \\
\text { terkait masih } \\
\text { kuatnya doktrin } \\
\text { kota santri pada } \\
\text { warga } \\
\text { Pandeglang, } \\
\text { sehingga } \\
\text { berpengaruh } \\
\text { terhadap } \\
\text { perkembangan } \\
\text { Pariwisata di } \\
\text { Pandeglang? }\end{array}$ & $\begin{array}{l}\text { Kami dari para alim ulama yang ada di } \\
\text { Pandglang pada dasaranya mendukung } \\
\text { perkembangan pariwisata yang ada di } \\
\text { Pandeglang, tapi harus disesuaikan } \\
\text { dengan kondisi budaya, dan kearipan } \\
\text { lokal yang ada, terutama terkait masih } \\
\text { kuatnya budaya Islam yang ada di } \\
\text { Pandeglang. }\end{array}$ \\
\hline 5. & $\begin{array}{l}\text { Pimpinan Pondok } \\
\text { Pesantren di Pandeglang. } \\
\text { (K.H. Muzami) }\end{array}$ & $\begin{array}{l}\text { Faktor apa yang } \\
\text { mendukung } \\
\text { begitu kuatnya } \\
\text { doktrin kota } \\
\text { santri yang ada } \\
\text { di Pandeglang, } \\
\text { sehingga } \\
\text { berpengaruh } \\
\text { kepada } \\
\text { perkembangan } \\
\text { pariwsiata di } \\
\text { Pandeglang? }\end{array}$ & $\begin{array}{l}\text { Kita tau bahwa sebagian warga } \\
\text { Pandeglang mayoritas muslim, dimana } \\
\text { peran ulama sangat kuat, termasuk } \\
\text { kebijakan pemerintah daerahpun tidak } \\
\text { luput dari campur tangan ulama, } \\
\text { sehingga wajar masyarakat Pandeglang } \\
\text { masih banyak yang mempertahankan } \\
\text { doktirn hukum islam tersebut. }\end{array}$ \\
\hline 6 & $\begin{array}{lrr}\text { Pihak } & \text { Akademisi } & \text { (Ibu } \\
\text { Pipin S.IP., } & \text { M.Si) } \\
\text { Sekolah Tinggi Ilmu } \\
\text { Pemerintahan (STISIP) } \\
\text { Banten Raya Pandeglang }\end{array}$ & $\begin{array}{l}\text { Bagaimana } \\
\text { pendapat ibu } \\
\text { terkait } \\
\text { perkembangan } \\
\text { pariwisata di }\end{array}$ & $\begin{array}{l}\text { Menurut saya perkembangan pariwisata } \\
\text { di Kabupaten Pandeglang masih jauh dari } \\
\text { harapan, pengelolaan masih kurang } \\
\text { maksimal, padahal potensinya banyak } \\
\text { dan bisa untuk di kembangkan dalam }\end{array}$ \\
\hline
\end{tabular}




\begin{tabular}{|c|c|c|c|}
\hline & & $\begin{array}{l}\text { Kabupaten } \\
\text { Pandeglang? }\end{array}$ & $\begin{array}{l}\text { rangka meningkatkan perekonomian } \\
\text { masyarakat Pandeglang itu sendiri }\end{array}$ \\
\hline 7 & $\begin{array}{ll}\text { Pihak Akademisi } & \text { (Gian } \\
\text { Sumarna } & \text { S.AP., } \\
\text { Dosen } & \\
\text { STIA } & \\
\text { Pandeglang } & \end{array}$ & $\begin{array}{l}\text { Bagaimana } \\
\text { pendapat ibu } \\
\text { selaku pihak } \\
\text { akademisi, } \\
\text { terkait masih } \\
\text { kurangnya } \\
\text { perkembangan } \\
\text { pariwisata di } \\
\text { Kabupaten } \\
\text { Pandeglang? }\end{array}$ & $\begin{array}{l}\text { Menurut saya banyak di sini terkait masih } \\
\text { kurangnya perkembangan dunia } \\
\text { pariwisata di Pandeglang, diantaranya: } \\
\text { masyarakat Pandeglang banyak yang } \\
\text { kurang sadar wisata seperti: banyak } \\
\text { pungutan liar, harga ditempat wisata } \\
\text { mahal, tidak bisa memberikan rasa aman } \\
\text { dan nyaman, yang membuat pengunjung } \\
\text { jadi kapok datang lagi ke tempat wisata } \\
\text { yang ada di Pandeglang, seharusnya } \\
\text { Dinas terkait bisa memecahkan masalah } \\
\text { tersebut diatas. }\end{array}$ \\
\hline 8 & $\begin{array}{lr}\text { Agus } & \text { Setiawan } \\
\text { (wisatawan } & \text { dari } \\
\text { Tangerang ) } & \end{array}$ & $\begin{array}{l}\text { Bagaimna } \\
\text { terkait } \\
\text { pariwisata di } \\
\text { Pandeglang? }\end{array}$ & $\begin{array}{l}\text { Saya bangga Pandeglang meimilki } \\
\text { banyak potensi, namun pengelolaanya } \\
\text { masih kurang, bnyak pungutan liar, } \\
\text { masih kurang nyaman dn aman, sering } \\
\text { terjadi pencurian, bikin kapok } \\
\text { pengunjung. }\end{array}$ \\
\hline 9. & $\begin{array}{l}\text { Haji.Sokip (wsiatawan } \\
\text { dari Tangerang) }\end{array}$ & $\begin{array}{l}\text { Bagaimana } \\
\text { kesanya setelah } \\
\text { berkunjung ke } \\
\text { kawasan wisata } \\
\text { di Pandeglang? }\end{array}$ & $\begin{array}{l}\text { Kesan saya : belum ada penataan tempat } \\
\text { wisata supaya lebih baik, masyarakatnya } \\
\text { masih banyak yang belum sadar wisata, } \\
\text { sampah masih berserakan, keamananya } \\
\text { masih kurang, dan sebagainya. }\end{array}$ \\
\hline 10 & $\begin{array}{l}\text { Yoga Adianto., SE.,MM } \\
\text { (wisatwan dari Serang) }\end{array}$ & $\begin{array}{l}\text { Boleh minta } \\
\text { pendapatnya } \\
\text { terkait tempat } \\
\text { wisata yang ada } \\
\text { di Padneglang? }\end{array}$ & $\begin{array}{l}\text { Bikin kapok karena para pedagang yang } \\
\text { ada di tempat wisata harganya terlalu } \\
\text { tinggi, juga parkir, dan banyak pengutan } \\
\text { liar, bikin males datang lagi, tolong Dinas } \\
\text { terkait supaya bisa mentertibkan } \\
\text { permasalahan tersebut. }\end{array}$ \\
\hline
\end{tabular}

\subsection{Faktor-faktor yang menghambat perkembangan pariwisata Pandeglang}

Kurangnya Budaya Sadar Wisata Masyarakat atau Pengunjung Kurangnya pengetahuan serta sikap sadar wisata masyarakat atau pengunjung menimbulkan berbagai hal yang tidak diinginkan seperti buang sampah sembarangan, coret-coret, bersikap apatis, banyaknya pungutan liar, kurang memberikan rasa aman, para pedagang di sekitar tempat wisata menentukan harga terlalu tinggi dan lain sebagainya. Hal ini menimbulkan kesan tidak terkelolanya dengan baik, sehingga salah satu penyakit masyarakat ini harus dikurangi dan dibasmi dengan cara mensosialisasikan budaya sadar wisata kepada masyarakat sekitar tempat wisata serta pengunjung objek wisata yang ada di Kabupaten Pandglang agar dapat menjaga dan melestarikan objek wisata pantai yang ada di Kabupaten Pandeglang baik kebersihan dan juga sarana prasarananya.

Kurannya Pembentukan Kelompok Sadar Wisata (Pokdarwis) yang ada di setiap kelurahan atau desa yang ada di Kabupaten Pandeglang, dengan demikian diharapkan Dinas Pariwisata Kabupaten Pandeglang untuk mensosialisasikan pembentukan Kelompok sadar wisata di setiap kelurahan atau desa yang ada di Kabupaten Pandeglang. 
Masih kuatnya Doktrin Kota Santri bagi sebagian masyarakat Kabupaten Pandeglang, dengan demikian di harapkan tokoh agama yang ada di masyarakat bekerjasama dengan dinas pariwisata, aparat desa dan jajaranya untuk mensosialisasikan pemahaman doktrin kota santri yang sebenarnya dan memberikan arahan akan pentingnya pengembangan strategi potensi wisata berbasis budaya atau kearipan lokal, dalam rangka meningkatkan perekonomian masyarakat. Kurangnya sarana dan prasarana, terutama akses jalan menuju tempat-tempat wisata yang masih rusak dan belum di perbaiki, hal ini disebabkan karena masih minimnya Anggaran Belanja Daerah di Kabupaten Pandeglang, apalagi sejak diterjang Tsunami Selat Sunda pada tanggal 22 Desember 2018.

\section{Tabel 4}

Matriks SWOT

\begin{tabular}{|c|c|c|}
\hline FaktorEksternal & $\begin{array}{l}\text { Strength (S) } \\
\text { 1. Banyak Potensi Wisata } \\
\text { 2. Wisata Pantai } \\
\text { 3. Wisata Pegunungan } \\
\text { 4. Wisata Air Panas } \\
\text { 5. Wisata Religi } \\
\text { 6. Wisata Pulau } \\
\text { 7. Wisata Air terjun } \\
\text { 8. Wisata Sejarah } \\
\text { 9. Wisata Cagar Budaya } \\
\text { 10.Wisata Mata air } \\
\text { 11.Di dukung Kementrian } \\
\text { Pariwisata \& Ekonomi } \\
\text { Kreatif baik pemerintah } \\
\text { daerah maupun pusat. }\end{array}$ & $\begin{array}{l}\text { Weakness }(\mathbf{W}) \\
\text { 1. Kurang sadar wisata } \\
\text { 2. Doktrin kota santri } \\
\text { 3. Minimnya APBD } \\
\text { 4. Aksen jalan rusak } \\
\text { 5. Kurangnya Pokdarwis } \\
\text { 6. Kuragnya promosi wisata } \\
\text { 7. Kurang kerjasama antara } \\
\text { pelaku usaha wisata } \\
\text { dengan Dinas Pariwisata } \\
\text { Pandeglang } \\
\text { 8. Kurangnya kualitas SDM } \\
\text { terkait wisata }\end{array}$ \\
\hline $\begin{array}{l}\text { Opportunity (O) } \\
\text { 1. Mememilki banyak } \\
\text { potensi wisata untuk bisa } \\
\text { di kembangkan } \\
\text { 2. Banyak sdm yang bisa } \\
\text { dikembangkan } \\
\text { 3. Promosi wisata bisa } \\
\text { menggunakan teknologi } \\
\text { informasi } \\
\text { 4. Pembentukan Pokdarwis } \\
\text { di setiap Desa atau } \\
\text { Kelurahan } \\
\text { 5. Mengiktui Pelatihan } \\
\text { Sadar wisata \& Teknologi } \\
\text { Informasi bagi pelaku } \\
\text { wisata dan kelompok } \\
\text { sadar wisata } \\
\text { 6. Memiliki Potensi wisata } \\
\text { yang unik. } \\
\text { 7. Adanya peran dari Dinas } \\
\text { Pariwista \& Ekonomi } \\
\text { Kreatif Kabupaten } \\
\text { Pandeglang }\end{array}$ & $\begin{array}{l}\text { Strategi SO (Growth) } \\
\text { 1. Mengikuti program } \\
\text { pengembangan potensi } \\
\text { wisata yang di adakan baik } \\
\text { oleh pemerintah maupun } \\
\text { pihak swasta. } \\
\text { 2. Pembentukan Kelompok } \\
\text { sadar wisata ( Pokdarwis) } \\
\text { di setiap Desa/Kelurahan } \\
\text { yang ada di Pandeglang } \\
\text { 3. Pelatihan sadar wisata bagi } \\
\text { Pokdarwis dan Masyarkat } \\
\text { sekitar tempat wisata } \\
\text { 4. Berkejsama antara Dinas } \\
\text { Pariwisata dengan Tokoh } \\
\text { agama terkait sosialisasi } \\
\text { makna Doktrin Kota santri. } \\
\text { 5. Pengembangan potensi } \\
\text { wisata di sesuaikan dengan } \\
\text { kearipan lokal yang ada di } \\
\text { Pandeglang }\end{array}$ & $\begin{array}{l}\text { Strategi WO (Stability) } \\
\text { 1. Mengikuti program } \\
\text { pengembangan potensi } \\
\text { wisata yang di adakan baik } \\
\text { oleh pemerintah maupun } \\
\text { pihak swasta. } \\
\text { 2. Pembentukan Kelompok } \\
\text { sadar wisata ( Pokdarwis) } \\
\text { di setiap Desa/Kelurahan } \\
\text { yang ada di Pandeglang } \\
\text { 3. Pelatihan sadar wisata bagi } \\
\text { Pokdarwis dan Masyarkat } \\
\text { sekitar tempat wisata } \\
\text { 4. Berkejsama antara Dinas } \\
\text { Pariwisata dengan Tokoh } \\
\text { agama terkait sosialisasi } \\
\text { makna Doktrin Kota } \\
\text { santri. } \\
\text { 5. Pengembangan potensi } \\
\text { wisata di sesuaikan dengan } \\
\text { kearipan lokal yang ada di } \\
\text { Pandeglang }\end{array}$ \\
\hline
\end{tabular}




\begin{tabular}{|c|c|c|}
\hline $\begin{array}{l}\text { 8. Bisa meningkatkan } \\
\text { perekonimian masyarakat. }\end{array}$ & $\begin{array}{l}\text { 6. Melakukan promosi wisata } \\
\text { dengan media teknologi } \\
\text { informasi atau online } \\
\text { 7. Melakukan kerjasama } \\
\text { anatar pelaku usaha wisata, } \\
\text { masyarakat, Dinas } \\
\text { Pariwisata Pandeglang. }\end{array}$ & $\begin{array}{l}\text { 6. Melakukan promosi wisata } \\
\text { dengan media teknologi } \\
\text { informasi atau online } \\
\text { 7. Melakukan kerjasama } \\
\text { anatar pelaku usaha } \\
\text { wisata, masyarakat, Dinas } \\
\text { Pariwisata Pandeglang. }\end{array}$ \\
\hline $\begin{array}{l}\text { Threat (T) } \\
\text { 1. Kurangnya kualitas sdm } \\
\text { pelaku usaha wisata \& } \\
\text { pokdarwis } \\
\text { 2. Kurangnya promosi } \\
\text { wisata } \\
\text { 3. Kurangnya pelatihan } \\
\text { sadar wisata bagi } \\
\text { pokdarwis } \\
\text { 4. Kurangnya pelatihan } \\
\text { teknologi informasi bagi } \\
\text { pelaku usaha wisata } \\
\text { 5. Masa pandemi covid-19, } \\
\text { bisa menghambat } \\
\text { perkembangan pariwisata. } \\
\text { 6. Kurangnya pelatihan } \\
\text { teknologi informasi bagi } \\
\text { pelaku usaha wisata. } \\
\text { 7. Kurangnya kerjasama } \\
\text { antara pelaku usaha wisata } \\
\text { dengan Dina Pariwisata } \\
\text { \& Ekonomi Kreatif } \\
\text { Pandeglang }\end{array}$ & $\begin{array}{l}\text { Strategi ST (Diversification) } \\
\text { 1. Mengikuti program } \\
\text { pengembangan potensi } \\
\text { wisata yang di adakan baik } \\
\text { oleh pemerintah maupun } \\
\text { pihak swasta. } \\
\text { 2. Pembentukan Kelompok } \\
\text { sadar wisata ( Pokdarwis) } \\
\text { di setiap Desa/Kelurahan } \\
\text { yang ada di Pandeglang } \\
\text { 3. Pelatihan sadar wisata bagi } \\
\text { Pokdarwis dan Masyarkat } \\
\text { sekitar tempat wisata } \\
\text { 4. Berkejsama antara Dinas } \\
\text { Pariwisata dengan Tokoh } \\
\text { agama terkait sosialisasi } \\
\text { makna Doktrin Kota santri. } \\
\text { 5. Pengembangan potensi } \\
\text { wisata di sesuaikan dengan } \\
\text { kearipan lokal yang ada di } \\
\text { Pandeglang } \\
\text { 6. Melakukan promosi wisata } \\
\text { dengan media teknologi } \\
\text { informasi atau online } \\
\text { 7. Melakukan kerjasama } \\
\text { anatar pelaku usaha wisata, } \\
\text { masyarakat, Dinas } \\
\text { Pariwisata Pandeglang. }\end{array}$ & 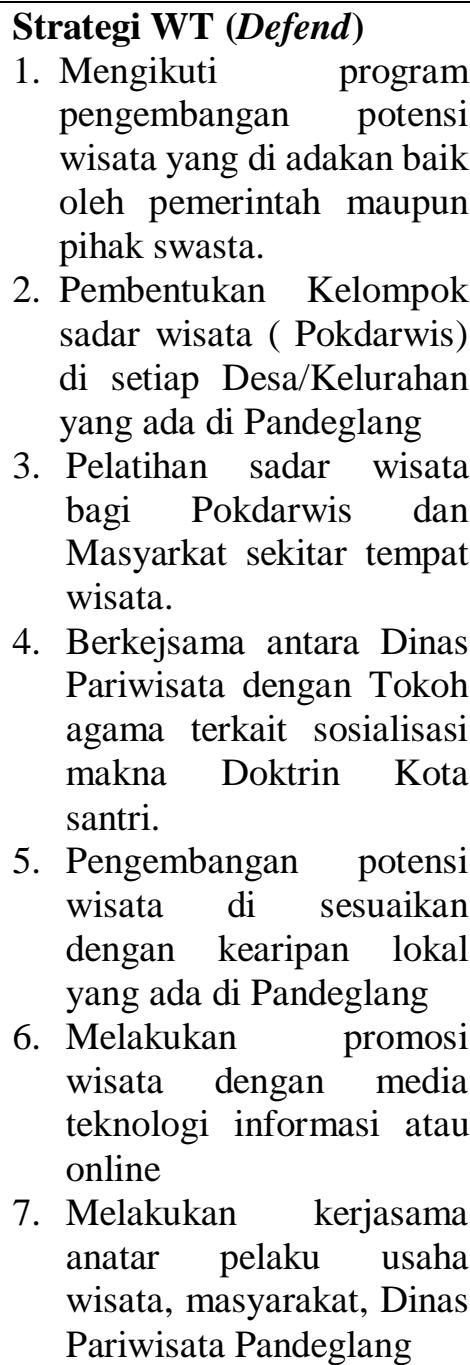 \\
\hline
\end{tabular}

Berdasarkan hasil analisis SWOT diatas, maka didapatkan strategi pengembangan Potensi Pariwisata yang ada di Kabupaten Pandeglang, yang tepat adalah Strategi SO (Growth).Strategi SO merupakan strategi yang memanfaatkan kekuatan yang ada untuk meningkatkan keunggulan kompetitifnya.Melalui strategi SO tersebut, Potensi Wisata yang ada di Kabupaten Pandeglang di harapkan menjalankan beberapa pengembangan diantaranya : pelatihan sadar wisata bagi kelompok sadar wisata dan masyarakat yang ada di sekitar tempat wisata, pengembangan teknologi informasi dalam rangka promosi wisata berbasis online.Strategi SO yang tertuang dalam matriks SWOT, menunjukan bahwa terdapat 7 (tujuh) strategi yang dapat dilakukan untuk mengembangkan potensi wisata yang ada di Kabupaten Pandeglang diantaranya: 
1. Mengikuti program pengembangan potensi wisata yang di adakan baik oleh pemerintah maupun pihak swasta.

2. Pembentukan Kelompok sadar wisata (Pokdarwis) di setiap Desa/Kelurahan yang ada di Pandeglang

3. Pelatihan sadar wisata bagi Pokdarwis dan Masyarkat sekitar tempat wisata

4. Pelatihan teknologi informasi bagi pelaku usaha wisata, dalam rangka promosi wisata melalui media online

5. Berkerjsama antara Dinas Pariwisata dengan Tokoh agama terkait sosialisasi makna Doktrin Kota santri, sehingga pemahaman makna kota santri tidak salah arah.

6. Pengembangan potensi wisata di sesuaikan dengan kearipan lokal yang ada di Pandeglang

7. Melakukan promosi wisata dengan media teknologi informasi atau online Melakukan kerjasama antara pelaku usaha wisata, masyarakat, Dinas Pariwisata dan Ekonomi Kreatif Kabupaten Pandeglang.

\section{Simpulan}

Berdasarkan hasil analisis dan pembahasan yang telah diuraikan sebelumnya, maka dapat disimpulkan bahwa terdapat permasalahan dalam proses prekembangan pariwisata yang ada di Kabupaten Pandeglang. Pertama, kurangnya budaya sadar wisata masyarakat atau pengunjung kurangnya pengetahuan serta sikap sadar wisata masyarakat atau pengunjung menimbulkan berbagai hal yang tidak diinginkan. Kedua, kurannya pembentukan kelompok sadar wisata (Pokdarwis) yang ada di setiap kelurahan atau desa yang ada di Kabupaten Pandeglang, masihnya kuatnya doktrin kota santri bagi sebagian masyarakat Pandeglang. Ketiga, kurangnya sarana dan prasarana, terutama akses jalan menuju tempat-tempat wisata yang masih rusak dan belum di perbaiki, kurangnya promosi dan even pariwisata di Kabupaten Pandeglang.

Hasil Penelitian perlu ada saran diantaranya yaitu pelatihan sadar wisata, pembentukan kelompok sadar wisata (Pokdarwis) ditiap kelurahan atau desa yang ada di Kabupaten Pandeglang, perbaikan sarana dan prasarana akses jalan menuju tempat wisata, toilet, parkir, pedagang, dan lain sebagainya. Selanjutnya, Dinas Pariwisata dan Ekonomi Kreatif Kabupaten Pandeglang lebih genjar lagi mengadakan even atau promosi wisata, dan mensosialisasi kan pemahaman makna kota santri kepada masyarakat yang ada disekitar potensi wisata yang ada di Kabupaten Pandeglang.

\section{Referensi}

Adnyana, I. M. (2020), Dampak Green Tourism Bagi Pariwisata Berkelanjutan Pada Era Revolusi Industri 4.0, Jurnal Ilmiah MEA (Manajemen, Ekonomi, \& Akuntansi), Vol. 4 No. 3, pp. 1582-1592.

Akib, E. (2020), Pariwisata Dalam Tinjauan Pendidikan: Studi Menuju Era Revolusi Industri, Pusaka: Journal of Tourism, Hospitality, Travel and Business Event, Vol. 2 No. 1, pp. 1-7.

Dinas Pariwisata Kabupaten Pandeglang Tahun 2020 
Indriani, E., Utomo, A., \& Edy, I. C. (2020), Model strategi penguatan daya saing industri kreatif pariwisata bernilai kearifan lokal, Deepublish, Yogyakarta.

Qamaruddin, M. Y., Sapar, S., Risal, M., \& Hamid, R. S. (2019), STRATEGI SIAPA MAU KERJA APA DALAM PENGEMBANGAN MODEL QUADRUPLE HELIX SINERGITAS ANTARA PEMERINTAH, PERGURUAN TINGGI, INDUSTRI, DAN MASYARAKAT, Jurnal Manajemen STIE Muhammadiyah Palopo, Vol. 4 No. 2. Pp. 13-23.

Risman, A., Wibhawa, B., \& Fedryansyah, M. (2016), Kontribusi Pariwisata Terhadap Peningkatan Kesejahteraan Masyarakat Indonesia. Prosiding Penelitian dan Pengabdian Masyarakat, Vol. 3 No. 1.

Santoso, M. B. (2017), PENGARUH CITY BRANDING "FRIENDLY AND RELIGIUS” DAN CITY IMAGE “KOTA SANTRI” TERHADAP KEPUTUSAN BELAJAR AGAMA (Studi kasus di Kabupaten Jombang Ponpes Tebuireng, Bahrul Ulum Tambak Beras, Mamba'ul Ma'arif Denanyar, Darul ulum Rejoso), Skripsi, STIE PGRI DEWANTARA.

Setyowati, N. A. (2019). PENGEMBANGAN OBJEK WISATA RELIGI MAKAM GUS DUR DI KABUPATEN JOMBANG, Skripsi, UPN Veteran Jawa Timur.

WIJAYA, S. (2019), PENGELOLAAN OBJEK WISATA AIR CIKOROMOY OLEH DINAS PARIWISATA KABUPATEN PANDEGLANG TAHUN 2017, Skripsi, Fakultas Ilmu Sosial dan Ilmu Politik, Universitas Sultan Ageng Tirtayasa. 